\title{
Mexico's Resilient Cast System: Managerial Implications For Foreign Firms
}

Rutilio Martinez, (Email: rutilio.martinez@unco.edu), University of Northern Colorado

Cris de la Torre, (Email: cris.delatorre@unco.edu), University of Northern Colorado

\begin{abstract}
Ethnically, three groups form Mexican society: Indians, Mestizos and Creoles. The Mestizos have European and Indian ancestors, while the Creoles have an ancestry that is exclusively European. Until the advent of NAFTA, the managerial profession functioned as an aristocracy, excluded the Indians and was dominated by the Creoles. NAFTA and accompanying free market policies are, however, transforming the managerial profession into a meritocracy, thus bringing Mestizos and Indians into this profession. For foreign firms this transformation causes managerial problems such as the reluctant acceptance of executives of Indian appearance and ethnically based disparities in executives' salaries.
\end{abstract}

\subsection{Introduction}

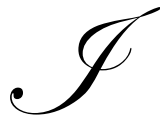

$\mathrm{n}$ colonial times wealth, power and social position in Mexico were distributed according to a very strict caste system. At the top were the Spaniards; in second place came the Creoles, who were descendants of Spaniards but who were born in Mexico. In third place came those who had Indian and Spanish ancestors, the Mestizos, and at the bottom came the Indians. Many of the Indians were slaves and almost all of them were very poor. The Mestizos, although not enslaved, also tended to live in acute poverty. Spaniards and Creoles owned land, mines, the few primitive industries that existed, occupied all the government positions and very rarely did any manual labor, for this kind of labor was reserved for the Indians and Mestizos. This system was legally abolished when Mexico became independent from Spain (1821). Later, the social and economic reforms brought about by the Revolution (1910-1917) were supposed to have eliminated any traces of the caste system. Yet, nowadays the rich are almost exclusively white, they form what some call the Creole oligarchy. Mestizos are predominant in the small middle and working classes, while the poor are primarily Indians and Mestizos of marked Indian ancestry. That is, in 2002 Mexico's caste system, while not as rigid as in colonial times, it is still very much in operation.

This resilient caste system is, however, clashing with the economic changes brought about by the North American Free Trade Agreement, NAFTA, and related free market policies. This treaty and accompanying policies have drastically increased the presence of foreign firms, the demand for labor at all levels and, to some extent, the degree of competition in most markets. These increases are transforming the management profession, from an aristocracy dominated by the Creole oligarchy into a meritocracy. As this transformation continues, Mestizos with predominant Indian background and Indians will be taking more and more positions in the managerial ranks, especially in the managerial ranks of foreign corporations. This has not and will not cause violent reactions, but it has not been and will not be welcomed by the Creole oligarchy. Hence, as foreign corporations include an increasing number of individuals of obvious Indian background in their managerial ranks, some managerial problems will result. This article analyzes some of the most visible of these problems.

The remainder of this article is organized as follows. The second section argues that there is, indeed, a racially based caste system in Mexican society. The third section explains why this system has been so resilient. The

Readers with comments or questions are encouraged to contact the authors via email. 
fourth section discusses some of the most visible managerial problems that disturbing the caste system is causing. The fifth section contains conclusions.

\subsection{The Problem That Is Not Supposed To Exist}

Most Mexicans flatly deny the existence of any kind of racial problems in their society. Several facts support the validity of this denial. There is not a single restaurant, recreational association, civic group, school, or organization of any kind that denies access to individuals who are of certain ethnic backgrounds. Official figures of the distribution of wealth iamong the races are non- existent, because neither the government nor society consider that race is a factor that influences wealth distribution. The last racial conflicts occurred during the "caste wars", in the state of Yucatan, at the end of the XIX century. The political leadership of the country has Creoles, Indians and Mestizos. The pre-colonial Indian past of the nation is revered, and the most respected presidents by the general population are Benito Juarez, an Indian, and Lázaro Cárdenas, a Mestizo. All these facts, though very visible, show a rosy but very incomplete picture of Mexico's racial reality.

An important missing element in this incomplete picture is the very unequal distribution of wealth among racial groups. The wealthy, as few foreign scholars have noticed, are almost exclusively white, while the Indians and many of the Mestizos are either poor or very poor (Nevaer 1995:102). Expensive private schools, which are supposed to be the best, have a student enrollment that is predominantly white ${ }^{1}$. Only Creoles form the leadership of Mexico's private sector (Jamar, Salaman and Kastelein 1998: 30-39). The most acute poverty in the nation is found in the southern states, where most of the population is Indian (INEGI 2002). The models and actors in television commercials and printed ads are mostly of Mediterranean European appearance because, according to some marketers, whites and Mestizos of European appearance, are the groups that have the resources to buy the products that are advertised (Moore 1997: 26-28) ${ }^{2}$. Whites, however, are a minority; they are no more than 10 percent of the population, while Indians are some 30 percent, with the rest of society being of mixed ancestry (CIA World Fact Book 2002). Hence, although no official statistics exist about the distribution of wealth among ethnic groups, it is clear that the Creole oligarchy owns and/or controls a very disproportionate part of the nation's wealth.

Completing the picture of Mexico's racial reality are the attitudes and feelings of the different ethnic groups towards each other. Mexican whites see their privileged economic and social position as their right. They tend to see the Indians and most Mestizos, especially those with predominant Indian features, such as dark skin, as lazy, inept, dirty and ugly; in short, as racially inferior. Furthermore, it is easy to find members of the Creole oligarchy who attribute Mexico's underdevelopment to the natural racial inferiority of Mestizos and Indians. The Mestizos also tend to see the Indians as inferior. In fact most Mestizos, especially those with fair complexions and European features, tend to hide or even deny their Indian ancestry. Their feelings toward the Creole oligarchy are, however, ambivalent. They vary between resentment and admiration. Indians tend to be submissive and have deep resentment towards the whites and Mestizos (Camp 1996: 24-25; Derossi 1971: 147; and Nevaer 1995: 101-103). These attitudes combined with a wealth distribution that favors the Creoles at the expense of the rest of society has an implication that many Mexicans deny: the caste system is still alive.

\subsection{The Resilient Caste System}

Slavery and the caste system were legally abolished when Mexico won its independence from Spain in 1821. Independence, however, did not result in the actual elimination of the caste system. From 1821 to 1876, Mexico was afflicted by several internal armed conflicts and a couple of harmful foreign interventions (Reynolds 1970: 15). These events combined with the presence of governments that were often inept and corrupt, precluded the design and implementation of public policies such as: land reform, a system of public education, construction of a basic communications infrastructure, and the adoption of laws that promoted industrial growth. This was, consequently, a period of economic stagnation, and hence, a period of marginal progress in the elimination of the colonial racial hierarchy.

During the 1876-1910 period, under the dictatorship of Porfirio Diaz, Mexico underwent solid economic growth but, for an independent nation, a notorious social deterioration. During his regime industrialization began, a 
communications infrastructure was developed, order prevailed and the economy expanded at a rate of 2.6 percent per year (Reynolds 1970: 23). Exports of a few agricultural goods and minerals led this sustained economic growth (Bulmer-Thomas 1995: 108). The distribution of wealth was, however, very biased. A very small group of foreign corporations owned the mines and 800 Creole families owned $97 \%$ of the national territory (Ministry of Budget and Programming 1985: 264). Public education was neglected and the income of workers and peasants was, often through violent repression, kept at minimal levels. Thus, by 1910 only $17 \%$ of the population was literate and extreme poverty characterized the living conditions of $90 \%$ of the population (Herring 1968: 335). Accompanying this severely skewed wealth distribution were racist attitudes of the Creole oligarchy. This oligarchy considered most Mestizos as racially inferior and the Indians as nothing more than bearers of burden (Herring 1968: 328). So, despite the absence of slavery and the presence of sustained economic growth, society during this period was, like in colonial times, organized in rigid and racially determined castes.

The political oppression, skewed wealth distribution, and extreme poverty of most of the population triggered the Revolution of 1910. The most violent phase of this conflict ended in 1917, but minor armed revolts and political instability continued to afflict the nation until 1929. In this year the predecessor of today's Revolutionary Institutional Party, the PRI, was established. The original members of the PRI were organized labor, the military leaders of the Revolution that were alive in 1929, and organizations of blue-collar workers. Later in 1936, the PRI brought into its membership a national organization that grouped the politically active peasantry (Gochman 1998: 152). Hence, since its beginnings, the membership of this party has been overwhelmingly composed of Indians and Mestizos. Despite this and despite the fact that the PRI won all the presidential elections between its foundation and 1994, the caste system, as said above, continues to exist.

Several factors explain the survival of the caste system under the PRI's revolutionary governments. The first factor is given by the initial endowments of wealth. During the PRI's first years almost all the Mestizos and Indians were destitute. Those with wealth were members of the Creole oligarchy. This oligarchy was, therefore, the only group that could start businesses in post-revolutionary Mexico. A second factor has been the low quality of public education at the elementary and secondary levels. Public education at these levels has been a priority for all the administrations since the 1930s, but the focus has been in quantity and little attention has been given to quality (Nevaer 1995: 57). A third factor is the consistent presence of labor surpluses; surpluses that have hindered the growth of wages, and thus, the economic standing of the working classes. A fourth, and perhaps the most important factor, is the economic model followed from 1929 to 1985.

During this period all the PRI administrations, whether conservative or liberal, followed very similar economic policies. All of them permitted or promoted the excessive regulation of business. All of these administrations subsidized industrial inputs like electricity, severely restricted imports through protectionist measures, and limited foreign investment to areas where such investment did not compete with domestic producers. In this environment rapid economic growth was achieved for a few decades, but the excessive regulations limited the number of new entrants and competitive markets were never created (Weintraub 1984: 77-91). In this environment business success depended on personal connections and on the bribing and lobbying of high-ranking government officials, rather than on the quality of the products and services offered. The absence of competition combined with the crucial role of personal networks created a business environment where the family firm, and thus nepotism, thrived (The Economist 1997: 6-9). Hence, progress in eliminating the colonial racial hierarchies within the private sector had to be marginal ${ }^{3}$.

The end of excessive protectionism and regulation began in August of 1982, when Mexico was unable to pay the interest on its $\$ 100$ billion foreign debt and the economy collapsed. To reactivate the economy, the De La Madrid administration (1982-1988) started to adopt free market policies in 1985. This process of economic liberalization moved very slowly until 1994, when the Salinas Administration (1988-1994) began the implementation of the North American Free Trade Agreement, NAFTA (Tornell 1995: 54-56). This treaty and accompanying free market policies transformed Mexico's economy; from inward looking to export oriented, and from almost closed to being one of the most open in the world (Quintin 2002: 1-3). These economic changes are, however, too recent to have, on their own, converted Mexico's aristocratic business culture into a meritocracy. Hence, foreign firms must still consider the caste system, as a cultural variable, in their business dealings in Mexico. 


\subsection{Managerial Implications Of The Fact That Ethnic Background Still Counts}

As a result of NAFTA and accompanying free market policies, from 1994 to 2000, Mexico received an average of $\$ 10.18$ billion dollars per year in foreign direct investment. These flows have produced a steady and very visible increase in the number of subsidiaries of foreign corporations in all sectors of the Mexican economy ${ }^{4}$. A growing share of these subsidiaries have started to serve Mexican markets, however, the great majority of these subsidiaries have been forming Mexico's dynamic exporting sector; sector that in 2001 had an output of \$158 billion or about one fourth of the country's GDP (INEGI 2002). Obviously, the subsidiaries of foreign corporations have also become major employers ${ }^{5}$. As these subsidiaries employ a growing share of the Mexican labor force, they have found that, in addition to cheap labor, the Mexican labor force also includes an adequate supply of capable managers (Sargent and Mathews 1998: 85-86). Unlike before NAFTA, a growing number of these managers do not come from the Creole oligarchy or from the group of Mestizos who have dominant European features, but from Mexico's working and low-income classes. Thus, a growing number of the Mexican nationals who are occupying managerial positions in foreign subsidiaries are either Mestizos with predominant Indian features or Indians. These newcomers to Mexico's managerial profession are encountering acceptance problems.

The Creole oligarchy is an important group that is especially reluctant to accept the newcomers into the managerial ranks. The newcomers are seen as people without class, as people who do not really belong to the executive ranks. The lack of acceptance is further accentuated by the fact that most of these newcomers obtained their education in state or in non-elite private universities. By having studied in state or private non-elite universities, the newcomers are excluded from the networks formed by managers and directors who studied in elite private universities.

The lack of acceptance of executives with obvious Indian features into the managerial classes is of relevance because the family firm still dominates Mexico's domestic business environment (Martínez and Dorfman 1998: 97). High-level transactions and the establishment of contracts and alliances are done through networks of business associates. Information, crucial for these transactions, is obtained through these networks (The Economist 1997: 7-9). Thus, the difficulties that the new comers face for entering into these networks could reduce their effectiveness in conducting business for their respective firms in the area of domestic business.

How to deal with the reluctant acceptance of the executives of obvious Indian background? According to executives from the textile industry of Puebla, by selecting those who, in addition to having good technical skills, have strong personalities, are openly proud of their Indian heritage, and are fully aware of the racial prejudices against Indians ${ }^{6}$.

A second acceptance problem that appointed executives of obvious Indian background are encountering, is with their ethnic peers. In Mexico's resilient caste society, tradition indicates that the boss is a white individual or a Mestizo who has a white appearance. In this society Indian and Mestizo subordinates do not easily welcome the appointment of an individual who is Indian or who has dominant Indian features as boss. For Mestizos and Indians the new boss would be, after all, one of them. According to the executives interviewed, acting in a very assertive and dictatorial manner will not help in the process of acceptance of the new Indian or Indian looking manager. To gain this acceptance, the appointed executives need to be able to communicate very well with subordinates; they need to have very good technical skills (these will contribute to giving them moral authority), and they have to show sincere respect and appreciation for the blue-collar workers of the firm.

It is often assumed that first generation descendants of Mexican immigrants in the USA are bicultural, that they know and can work in the culture of the USA and in the culture of Mexico. This assumption, according to executives of the textile industry of the city of Puebla, has lead American firms, with no experience in this country, to appoint Mexican Americans as executives in their Mexican operations. This has been, according to the interviewed executives, a remarkable unsuccessful move. First, because most Mexican Americans are unaware of the deep racial divide that exists in Mexico. Second, because the Creole oligarchy saw these Mexican Americans as second class Americans, as Indians or Mestizos whose economic status improved as a result of the migration of their parents, but still as racially inferior. Third, because Mexican executives, regardless of ethnic background, seriously 
resented the fact that these transferred Mexican Americans were paid better than them. Fourth, and last, because the Creole businessmen expected Mexican American executives to be fully bilingual, but this is an attribute that very few Mexican Americans have.

Observant foreign executives will soon notice that the authoritarian form of management is very common in Mexican firms of all sizes. Observant foreign executives will also notice that in quite a few Mexican firms, like in the textile factories owned by members of the Creole oligarchy in the city of Puebla, the labor force is treated in abusive and unfair ways. These behaviors are logical consequences of the caste system that have induced foreign managers to treat the Mexican laborers in a harsh way. Executives from the textile industry of Puebla stated that Korean executives who did this ran into very serious problems with the unions and the Mexican labor authorities. The interviewed executives argued that the Creoles get away with their unfair behavior because the Creoles are not seen as foreigners, and because they know how to manipulate the labor authorities and the union leaders. According to the interviewed executives, despite the continued existence of the caste system and the bad example of the firms owned by Creoles, foreign companies would be better off by using participative styles of management and by treating the labor force with respect. This view is not exclusive of the interviewed executives. A survey of executives from assembly plants owned by foreign corporations found that this style of management has given positive results (Sargent and Mathews 1998: 89-92).

Salaries of recent college graduates are also affected by the caste system. As mentioned above, elite private universities have a student population which is predominantly white, while the state and non-elite private universities have student populations formed primarily with Mestizos and Indians. Graduates from the elite private universities tend to command significantly higher salaries than graduates from state and non-elite private schools. A primary reason for the disparity in salaries is based upon the widely accepted assumption that the elite private universities are much better than the state and non-elite private universities. This assumption is probably valid in the field of business administration. In this area there are two elite private schools that have received accreditation from the American Association of Collegian Business Schools, the AACSB ${ }^{7}$. In the area of engineering, however, there are no associations, government agencies or groups of professionals that had conducted studies that classify engineering programs according to their academic quality. Nor is there a significant difference in the academic credentials of the faculties of the different engineering programs. From the elite private schools to the least expensive state university, the faculties of the schools of engineering are usually formed with adjunct professors who rarely have advanced degrees. Thus, for a company that hires engineers for what they know and their skills, rather than for their racial appearance, the issue of from which universities to recruit should be based on cost minimization not in the alleged academic prestige of the university.

In Mexican firms, regardless of size, the decision-making authority tends to be highly centralized in the owner and his immediate subordinates; subordinates who are often relatives or close friends of the owner (The Economist 1997: 7-9). Given this tradition and the continued existence of the caste system, it follows that in large to mid-size firms, the decision-making authority would, in all likelihood, fall to individuals who have a European appearance. Thus, foreign executives who do business with large and mid-size Mexican companies would have to pay attention to the ethnic background of the Mexican executive with whom they are dealing. If the Mexican executive is of European appearance, then this executive is likely to have decision-making authority. Conversely, if the executive has Indian appearance, a very rare occurrence, then the decision-making authority of this executive, regardless of title, is very likely to be marginal or non-existent

Trying to deal with this racial hierarchy by hiring managers who have the adequate racial background, that is, individuals who are members of the Creole oligarchy could also be a serious mistake. Individuals from this oligarchy are likely to have the right social and educational credentials. Yet the companies hiring them must not overlook the fact that the privileged position of these individuals might have more to do with their ethnicity than with their merits and skills. Hence, foreign firms trying to avoid the problems created by Mexico's racial hierarchy by appointing Creoles to executive positions; must make every effort to check that the selected individual is capable of doing the work for which he was hired. 


\subsection{Conclusions}

The existence of Mexico's resilient caste system is denied by most Mexicans and ignored in the literature about the cultural traditions that foreign firms face in this country. Despite this, foreign firms setting operations in Mexico sooner or later realize that, according to this system, Indians and Mestizos who look Indian are not welcomed in the upper echelons of management. These firms, however, also have to realize that as Mexico continues to modernize its, their managerial teams will have to include a good number of individuals of obvious Indian background, thus challenging Mexico's traditional racial hierarchy. To deal effectively with this challenge, foreign firms will have to select managers who are fully aware of Mexico's racial reality, who have good technical skills and the personality to deal with this reality.

NAFTA and accompanying free market policies will, inevitable, transform Mexico's business environment, from an aristocracy into a meritocracy, thus finally eliminating the racial hierarchy that has prevailed for centuries in Mexico. Hence NAFTA and related free market policies will finally do what independence, revolution and 71 years of so-called revolutionary governments, could not do: eliminate the caste system. If this happens, it will be a lesson for the rest of Latin America, where the caste system is even more ingrained than in Mexico.

\section{End Notes}

\footnotetext{
${ }^{1}$ There are no statistics showing the relative participation of each ethnic group in the enrollments of the elite private schools. However, a visit to the campuses of the Mexico's most expensive universities such as the Tecnologico de Monterrey, the ITAM, the Universidad Iberoamericana, the Universidd Anáhuac and the Universidad de las Américas- Puebla, will convince anyone that, in these schools, Mestizos with marked Indian features are a minority while Indians are practically absent.

i2 The dean of the school of business of the Universidad de las Américas-Puebla, who has a Ph. D. in marketing from Texas A\&M, stated in an interview that the practice of using European looking models in T.V. commercials and printed ads is not exclusively the result of a severely skewed income distribution in favor of the Creole oligarchy. He stated that this practice is also explained by the fact that, in Mexican society, the European appearance is consider pretty and sophisticated, while the Indian appearance is considered ugly and unsophisticated.

3 Close observers of Mexican society could easily argue that despite the revolutionary ideals of the PRI and the federal government, Creoles and few Mestizos have dominated the leadership of these institutions, while Indians have been conspicuously absent. Hence, the continued existence of the colonial racial hierarchies in the private sector should not be considered abnormal, given that these hierarchies have also continued to exist in the institutions that were supposed to be agents of change.

${ }^{4}$ From the perspective of the Mexican government, one of the aims of NAFTA and accompanying free market policies was to make foreign direct investment the moving force of the economy (Ortiz 1994: 159).

${ }^{5}$ In 1994, the year NAFTA began, the assembly plants owned mostly by foreign corporations and known as maquiladoras, exported almost $\$ 30$ billion and generated close to $20 \%$ of total manufacturing employment, which represented about 450 thousand jobs (Vargas 1998: 2). By 2000, from January to September, maquiladoras exported $\$ 57.3$ billion, which represented $54 \%$ of Mexico's manufacturing exports and employed over 1.2 million workers (Vargas 2000: 2).

${ }^{6}$ The executives interviewed worked for AZT International. This is an American owned assembly plant that produces denim pants. The interviews were conducted on September 2002.

The business schools of the Instituto Tecnológico Autónomo de México, the ITAM, and the Instituto Tecnológico y de Estudios Superiores de Monterrrey, the ITESM, campus Monterrey are the only two AACSB accredited institutions in Mexico. These schools received their accreditation in 1999.
}

\section{References}

1. Bulmer-Thomas, Victor. The Economic History of Latin America Since Independence. New York, N.Y.: Cambridge University Press, 1994

2. Camp, Roderic. Politics in Mexico. New York, N.Y.: Oxford University Press, 1996.

3. CIA. The World Fact Book. www.cia.gov Accesses 28 December 2002

4. Derossi, Flavia. The Mexican Entrepreneur. Paris, France: O.E.C.D. Publications, 1971.

5. Gochman, Benjamin. Networks, Neoliberalism, and NAFTA: Economic Technocrats and Policy Change in Mexico, 1982-1997. Denver, CO.: Unpublished dissertation, University of Denver, School of International Studies, 1998.

6. Herring, Hubert . A History of Latin America. New York, N.Y.: Alfred A. Knopf, 1968. 
7. Jamar, Christen, Salaman, Rachel and Kastelein, Barbara. "Power Houses." US/MexicoBusiness. Volume V, Number 8, November 1998.

8. INEGI. www.inegi.gob.mx Accessed 25 December 2002.

9. Martínez, Sandra and Dorfman, Peter. The Mexican Entrepreneur. An Ethnographic Study of the Mexican Empresario." International Studies of Management and Organization. Volume 28, Number 2, Summer 1998.

10. Ministry of Budget and Programming. Historical Statistics of Mexico Volume 1. Mexico D.F.: Ministry of Budget and Programming, 1985

11. Moore, Leslie. "The Hippest Adguys in Mexico." US/Mexico Business. November 1997.

12. Ortiz, Edgar. "NAFTA and Foreign Investment in Mexico." Foreign Investment and NAFTA. Edited by Rugman, Alan. Columbia, S.C.: University of South Carolina Press, 1994.

13. Quintin, Erwan. "Is Mexico Ready to Roar." Southwest Economy. Dallas, TX.: Federal Reserve Bank of Dallas, Issue 5, September/October 2002.

14. Reynolds, Clark W. The Mexican Economy Twentieth-Century Structure and Growth. Yale University Press, 1970

15. Sargent, John and Mathews, Linda. "Expatriate Reduction and Mariachi Circles. Trends in MNC Human-Resource Practices in Mexico." International Studies of Management \& Organization. Volume 28, Number 2, Summer 1998.

16. The Economist. "Survey: Business in Latin America." The Economist. December 6 ${ }^{\text {th }}, 1997$.

17. Tornell, Aaron. "Are Economic Crises Necessary for Trade Liberalization and Fiscal Reform? The Mexican Experience." Reform, Recovery and Growth: Latin America and the Middle East. Edited by Dornbusch, Rudiger and Edwards, Sebastian . Chicago, Ill.: The University of Chicago Press, 1995.

18. Vargas, Lucinda. "The Maquiladora Industry in Historical Perspective (Part 1)." Business Frontier. El Paso, TX.: Federal Reserve Bank of Dallas, El Paso Branch, Issue, 1998.

19. . "Maquiladoras 2000: Still Growing." Business Frontier. El Paso, TX.: Federal Reserve Bank of Dallas, El Paso Branch, Issue 3, 2000.

20. Weintraub, Sidney. Trade between Mexico and the United States?. Washington, D.C.: The Brookings Institution, 1984.

Notes 
Notes 